\title{
Consulting patterns after a television programme on sexually transmitted diseases*
}

\author{
M W ADLER \\ From the Academic Department of Genitourinary Medicine, Middlesex Hospital Medical School, London
}

SUMMARY The effect on the work load in one of two clinics featured in a television programme devoted to the sexually transmitted diseases was monitored. The patients' source of referral was recorded before and after the programme and the number of telephone inquiries noted during the same periods. For the two weeks after the programme $18 \%$ of the male patients and $13 \%$ of the female patients attending the clinic came as a result of watching it. A sexually transmitted disease was diagnosed in $30 \%$ and $22 \%$ of those men and women respectively. This proportion of positive diagnoses was lower than for other sources of referral. The mean number of telephone inquiries rose by $56 \%$ after the programme.

\section{Introduction}

One of the problems facing those working in the specialty of genitourinary medicine, in which most patients are self-referred, is how best to encourage patients to attend clinics. In particular data on how effective education through the media-by newspaper articles, radio, and television programmes-is in informing the public about the diseases and where to seek treatment are limited and difficult to obtain. ${ }^{1-5}$

In April 1981, BBC television showed a 50-minute programme on the sexually transmitted diseases (STDs). This "Man Alive" programme discussed the increase in the incidence of the diseases and the clinical symptoms and investigation of the more important infections. Two hospitals (Middlesex and Westminster hospitals) and their consultants were featured extensively during the programme. Since I expected that this would have an effect on the work load in these two clinics as well as in others the effect of the programme on this department, and whether this method of presenting information to the public encouraged patients with STDs to attend the clinic, was studied.

\section{Patients and methods}

Records were kept of the patients' sources of referral to the clinic for two weeks before and after the pro-

\footnotetext{
* A shortened version of this paper has already been published $(\mathrm{Br}$ Med J 1981: 283: 1395).

Address for reprints: Professor M W Adler, Academic Department of Genitourinary Medicine, Middlesex Hospital Medical School, London W1N 8AA

Accepted for publication 2 February 1982
}

gramme and of any telephone inquiries during the same periods. The referral source was recorded only for new patients who had never attended the clinic previously. The consulting doctor was asked to note on a special recording sheet the exact way in which the patient had heard of the clinic and been referred. The following options were listed: (a) letter (general practitioner, family planning/pregnancy advice clinic, and other); (b) verbal (sexual contact, friend, and family planning/pregnancy advice); (c) contact slip produced by the patient; (d) educational/advertising (pamphlets, toilet notices, television programmes, radio programmes, newspapers, or magazine articles); and (e) other reasons.

For administrative reasons the monitoring of telephone inquiries was limited to female patients. All calls were answered by the nursing staff, who were asked to record details of their conversation in a standard manner. Since it was not always possible to distinguish old from new patients, inquiries by both were included.

\section{Results}

SOURCE OF REFERRAL

During the two weeks before the television programme a total of 351 new patients were seen in the clinic (190 men and 161 women). In the two weeks after the programme 441 new patients attended (250 men and 191 women). The sources of referral for male and female patients for the two weeks before and after the programme are shown in table I.

\section{Before the programme}

The commonest source of referral for both male and female patients before the programme was by verbal 
TABLE I Source of referral to clinic before and after television programme

\begin{tabular}{|c|c|c|c|c|}
\hline \multirow[b]{2}{*}{ Source of referral } & \multicolumn{2}{|l|}{$\operatorname{Men}(\%)$} & \multicolumn{2}{|l|}{ Women $(\%)$} \\
\hline & $\begin{array}{l}\text { Before } \\
(n=190)\end{array}$ & $\begin{array}{l}\text { After } \\
(n=250)\end{array}$ & $\begin{array}{l}\text { Before } \\
(n=161)\end{array}$ & $\begin{array}{l}\text { After } \\
(n=191)\end{array}$ \\
\hline $\begin{array}{l}\text { Letter } \\
\text { Verbal }\end{array}$ & \multicolumn{3}{|c|}{ Verbal } & $12 \cdot 6$ \\
\hline Sexual contact & $6 \cdot 3)$ & $4 \cdot 8)$ & $9 \cdot 9)$ & $9 \cdot 4)$ \\
\hline Friend & $38 \cdot 4$ & $28 \cdot 4$ & $20 \cdot 5$ & $17 \cdot 3$ \\
\hline Family planning/pregnancy advice clinic & $\{5$ & $\{39 \cdot 2$ & $36 \cdot 0\} 68 \cdot 9$ & $20 \cdot 4\} 52 \cdot 3$ \\
\hline $\begin{array}{l}\text { General practitioner } \\
\text { Other }\end{array}$ & $\left.\begin{array}{l}9 \cdot 0 \\
1 \cdot 0\end{array}\right)$ & $\left.\begin{array}{l}5 \cdot 6 \\
0 \cdot 4\end{array}\right)$ & $2 \cdot 5$ & $5 \cdot 2$ \\
\hline Contact slip & $3 \cdot 7$ & $2 \cdot 4$ & $13 \cdot 1$ & $7 \cdot 8$ \\
\hline Television programme(s) & $0 \cdot 5$ & $18 \cdot 0$ & & $12 \cdot 6$ \\
\hline Toilet notices & $1 \cdot 6$ & $0 \cdot 8$ & & \\
\hline Radio/newspaper/magazines & $5 \cdot 3$ & $2 \cdot 4$ & & $1 \cdot 6$ \\
\hline Telephone book/gay switchboard & $15 \cdot 3$ & $8 \cdot 8$ & $5 \cdot 0$ & $4 \cdot 2$ \\
\hline Other & $10 \cdot 5$ & $16 \cdot 8$ & $6 \cdot 8$ & $8 \cdot 9$ \\
\hline
\end{tabular}

contact: with a sexual contact, a friend, a family planning or pregnancy advice clinic, or a general practitioner. For male patients the commonest source was a friend who was not a sexual contact, whereas for women this was the second commonest source after family planning and pregnancy advice clinics. Apart from these clinics, the medical and ancillary professions played little part in referring patients to the clinic. Eight per cent of men and $6 \%$ of women were referred with a doctor's letter, either from their general practitioner or a family planning clinic. The telephone directory and "gay" switchboard produced more male consultations $(15 \%)$ than visits to and referrals by general practitioners. The media were rarely cited as the source of referral by men (television programmes $0.5 \%$, radio, magazine, and newspaper articles 5\%) and never by women.

Some of the "other" sources of referral provided an interesting insight into some rarer methods: for example, a prostitute told her client to go to the clinic with his penile wart, a wife found her husband's appointment card, and a patient asked her taxi driver to take her to the "best" clinic.

\section{After the programme}

After the television programme the commonest source of referral for men was still by verbal contact. Nevertheless, $18 \%$ of male patients visited the clinic as a direct result of watching the television programme. Similarly, the commonest source of referral for female patients was still by verbal contact, but $13 \%$ of patients attending during the two weeks after the programme indicated that it had been the reason for their attendance.

\section{DIAGNOSES}

The eventual diagnoses made in patients attending after the programme were recorded in relation to the source of referral (table II). The 250 male patients were responsible for 256 diagnoses or cases, since some had more than one disease at the time of consultation. Fifty per cent (129) of male cases seen during the two weeks were sexually transmissible in origin (non-specific genital infection 64, gonorrhoea 21 , genital warts 14 , genital herpes 14 , syphilis 6 , pediculosis pubis 4 , trichomoniasis 4 , and scabies 2 ).

TABLE II Diagnosis by source of referral to clinic after television programme

\begin{tabular}{|c|c|c|c|c|c|c|c|c|c|c|c|c|c|}
\hline \multirow[b]{3}{*}{ Source of referral } & \multicolumn{6}{|l|}{ Men } & \multicolumn{7}{|c|}{ Women } \\
\hline & \multicolumn{2}{|c|}{ Total No } & \multicolumn{3}{|c|}{ Diagnosis } & \multirow[b]{2}{*}{$\begin{array}{l}\text { Total } \\
(\%)\end{array}$} & \multicolumn{2}{|c|}{ Total No } & \multicolumn{4}{|c|}{ Diagnosis } & \multirow[b]{2}{*}{$\begin{array}{l}\text { Total } \\
(\%)\end{array}$} \\
\hline & Cases & Patients & $\begin{array}{l}S T D \\
(\%)\end{array}$ & $\begin{array}{l}\text { Other } \\
\text { diseases } \\
(\%)\end{array}$ & $\begin{array}{l}N A D \\
(\%)\end{array}$ & & Cases & Patients & $\begin{array}{l}S T D \\
(\%)\end{array}$ & $\begin{array}{l}\text { Candi- } \\
\text { dosis } \\
(\%)\end{array}$ & $\begin{array}{l}\text { Other } \\
\text { diseases } \\
(\%)\end{array}$ & $\begin{array}{l}N A D \\
(\%)\end{array}$ & \\
\hline $\begin{array}{l}\text { Letters } \\
\text { Verbal } \\
\text { Other }\end{array}$ & $\begin{array}{l}31 \\
99 \\
80\end{array}$ & $\begin{array}{l}29 \\
98 \\
78\end{array}$ & $\begin{array}{l}64 \cdot 5 \\
57 \cdot 6 \\
47 \cdot 5\end{array}$ & $\begin{array}{l}25 \cdot 8 \\
12 \cdot 1 \\
20 \cdot 0\end{array}$ & $\begin{array}{r}9 \cdot 7 \\
30 \cdot 3 \\
32 \cdot 5\end{array}$ & $\begin{array}{l}100 \cdot 6 \\
100 \cdot 0 \\
100 \cdot 0\end{array}$ & $\begin{array}{r}25 \\
108 \\
47\end{array}$ & $\begin{array}{r}24 \\
100 \\
43\end{array}$ & $\begin{array}{l}36 \cdot 0 \\
32 \cdot 4 \\
42 \cdot 6\end{array}$ & $\begin{array}{l}16 \cdot 0 \\
15 \cdot 7 \\
25 \cdot 5\end{array}$ & $\begin{array}{r}16 \cdot 0 \\
13 \cdot 0 \\
4 \cdot 2\end{array}$ & $\begin{array}{l}32 \cdot 0 \\
38 \cdot 9 \\
27 \cdot 7\end{array}$ & $\begin{array}{l}100 \cdot 0 \\
100 \cdot 0 \\
100 \cdot 0\end{array}$ \\
\hline $\begin{array}{l}\text { Total of sources excluding } \\
\text { television programme } \\
\text { Television programme }\end{array}$ & $\begin{array}{r}210 \\
46\end{array}$ & $\begin{array}{r}205 \\
45\end{array}$ & $\begin{array}{l}54 \cdot 8 \\
30 \cdot 4\end{array}$ & $\begin{array}{l}17 \cdot 1 \\
23 \cdot 9\end{array}$ & $\begin{array}{l}28 \cdot 1 \\
45 \cdot 7\end{array}$ & $\begin{array}{l}100 \cdot 0 \\
100 \cdot 0\end{array}$ & $\begin{array}{r}180 \\
27\end{array}$ & $\begin{array}{r}167 \\
24\end{array}$ & $\begin{array}{l}35 \cdot 6 \\
22 \cdot 2\end{array}$ & $\begin{array}{l}18 \cdot 3 \\
29 \cdot 6\end{array}$ & $\begin{array}{l}11 \cdot 1 \\
14 \cdot 8\end{array}$ & $\begin{array}{l}35 \cdot 0 \\
33 \cdot 4\end{array}$ & $\begin{array}{l}100 \cdot 0 \\
100 \cdot 0\end{array}$ \\
\hline Total of all sources & 256 & 250 & $50 \cdot 4$ & $18 \cdot 3$ & $31 \cdot 3$ & & 207 & 191 & $33 \cdot 8$ & $19 \cdot 8$ & $11 \cdot 6$ & $34 \cdot 8$ & \\
\hline
\end{tabular}

$\chi_{2}^{2}=9 \cdot 096, \mathrm{P}<0 \cdot 02$ 
The next most common diagnosis ( $31 \%$ of cases) was "nothing abnormal detected". The remaining cases $(\mathbf{1 8 \%})$ were non-sexually transmitted conditions that required advice or treatment.

The contribution made to the various diagnostic categories by those patients who had watched the programme can be compared with that made by patients from the other referral sources both separately and together. Although $30 \%$ of television viewers had an STD, this source of referral produced a lower yield of positive diagnoses than any other (letters $64 \%$, verbal $58 \%$, and "other" $47 \%$ ). All the sources together excluding television also produced a higher yield than television (55\% compared with $30 \%$ ). The commonest diagnosis among those attending as a result of the programme was that nothing abnormal was found $(\mathbf{4 6 \%})$. In contrast, $28 \%$ of patients from other referral sources were given this diagnosis. The difference in diagnoses between those coming to the clinic as a result of the programme and those referred by other sources was statistically significant $(\mathrm{P}<0 \cdot 02)$.

The 191 new female patients seen in the clinic after the programme were responsible for 207 diagnoses or cases. Most of these were cases in which nothing abnormal was found (35\%). In $34 \%$ (70 cases) a sexually transmitted disease was diagnosed: nonspecific genital infection 21, trichomoniasis 14, gonorrhoea 14, genital warts 13 , genital herpes 5 , syphilis 2 , and pediculosis pubis 1 . The remaining cases were either of candidosis $(20 \%)$ or other diseases that required treatment or advice but were not sexually transmitted $(12 \%)$.

Like the male patients women attending as a result of the programme produced a lower yield of STDs $(22 \%)$ than any other source of referral ("other" $43 \%$, letters $36 \%$, and verbal contact $32 \%$ ). All the sources together excluding television produced a higher yield than television (36\% compared with $22 \%$ ), although this difference was not statistically significant. The two commonest diagnoses among patients attending as a result of the programme were "nothing abnormal found" (33\%) and candidosis $(30 \%)$.

\section{TELEPHONE INQUIRIES}

The total number of telephone inquiries made by female patients during the two weeks before the television programme was 169 (mean 16.9 a day) and during the two weeks after 264 (mean $26 \cdot 4$ a day). This represents a rise in calls of $56 \%$, which is statistically significant $(P<0 \cdot 01)$. Not all the telephone inquiries after the programme resulted from it, but it was not possible in all instances to elicit whether the programme had caused the inquiry. The nurses answering the telephone often found it hard to gather this information and had the impression that patients were reluctant to admit to having seen it lest they be considered hypochondriacal. Despite this, the increase in calls was clear-cut and was probably due to the television programme. This is partially confirmed by the fact that the mean number of calls a day dropped to 12.5 in the third and fourth weeks after the programme, when the effect and impact would have worn off.

\section{Discussion}

The present study has shown that for two weeks after the television programme just under one-fifth of male patients and one-eighth of female patients attended this clinic as a result of the programme and that an STD was diagnosed in less than one-third of the men and one-quarter of the women. This proportion of positive diagnoses was lower than for other sources of referral. It would be too simple an interpretation to suggest that the programme resulted in only the anxious and hypochondriacal seeking advice since STDs can often be asymptomatic, and in women even the presence of symptoms does not indicate disease. These two problems make it difficult for a person to decide whether or not they have a disease and need to seek advice. Any health information must emphasise these points about symptoms, but unless the information is expanded on a situation will occur in which a large number of patients will be found to have no disease or to have commoner conditions (for example, candidosis) with identical symptoms to those of the real and serious STDs. The information needs to be expanded so that patients can determine to what extent they are at risk. For example, a patient at high risk would be one with a recent change in sexual partner, either of their own or of their partner, multiple sexual contacts, recurrent or persistent symptoms after treatment, and symptoms in sexual partners. Physicians working in genitourinary medicine, who are aware of the poor discriminating power of symptoms and the asymptomatic nature of the diseases, have rightly encouraged patients to attend for routine examinations. This approach should continue but would produce a higher yield of cases of STD if information about the risk of disease was publicised. Even though the work load after the programme was not excessive, future programmes should be more finely tuned to disseminate this information. The media are unlikely to cease to be interested in STDs, but they could benefit from our experience after the television programme. Goodchild ${ }^{6}$ makes it clear that the programme producer is more interested in journalism than in providing a public service; "In dealing with the groups at risk and providing them with crucial 
information, such programmes (on STD) seem to be of only marginal use". This is also suggested by Schofield, ${ }^{7}$ who found that young people rarely $(6 \%)$ admitted that television had been the source of their information about STDs.

An extremely elaborate prospective research project would be needed to assess accurately the true effect of a television programme, media or health education campaign. Samples of non-attenders as well as attenders and of those who had modified their chances of contracting disease as a result of the new information on STDs would need to be studied. Hopefully, those individuals watching the programme, who had no need to attend a clinic, will have received enough information to do so should they develop a disease or see themselves at risk in the future. Even though most patients coming to the clinic as a result of the programme had no disease they will continue to be sexually active and some will contract a disease in the future. Thus, the education afforded by their attendance and a sympathetic reception should both help to prevent disease and, hopefully, encourage those at risk to attend a clinic more readily again at a later date.
I am grateful to all the doctors and nurses working within the clinic for their help in collecting the information and to Elizabeth Belsey for her assistance.

\section{References}

1. Dalzell-Ward AJ. Forward planning in the United Kingdom for anti-VD education. $\mathrm{Br} J$ Vener Dis 1970; 46: 159.

2. Dalzell-Ward AJ. The design of action research experimental campaigns. Br J Vener Dis 1973;49: 171.

3. Health Education Council. The Control of the Spread of Gonorrhoea. A Health Education Exercise to Improve Contact Tracing. Final Report. Mimeo. London: Health Education Council, 1975.

4. Rowntree FD. Health education. In: Morton RS, Harris JRW eds. Recent Advances in Sexually Transmitted Diseases. Edinburgh: Churchill Livingstone 1975:388-401.

5. World Health Organisation. Social and health aspects of sexually transmitted diseases-principles of control measures. Public Health Papers No 65. Geneva: World Health Organisation, 1977.

6. Goodchild $\mathbf{P}$. The role and responsibility of the mass media in the UK In: Catterall RD, Nicol CS, eds. Sexually Transmitted Diseases. London: Academic Press, 1976:245-50.

7. Schofield M. Sexual Behaviour of Young Adults. London: Allen Lane, 1973. \% 